\title{
Identification of Plasma Cells in Lung Alveoli and Interstitial Tissues After Localized Lung Immunization
}

\author{
David E. Bice, Robert H. Gray, Michael J. Evans, and Bruce A. Muggenburg \\ Inhalation Toxicology Research Institute, Lovelace Biomedical and Environmental Research \\ Institute, Albuquerque, New Mexico
}

\begin{abstract}
Large numbers of antibody-forming cells (AFC) can be identified with the Jerne plaque assay in immunized lung lobes of the beagle dog after localized instillation of particulate antigen. Published data suggest that these AFC are secreting antibody and are responsible for increased levels of specific antibody in immunized lung lobes. If AFC in the lung are actively secreting antibody, there should be an increase in the number of mature plasma cells in lung lobes exposed to antigen. The purposes of this study were to evaluate the number of lymphoid cells present in immunized and control lung lobes and to determine if lung immunization produces a localized increase in the number of plasma cells. Sheep red blood cells (SRBC), autologous dog red blood cells, and saline were instilled into specific lung lobes of beagle dogs with the ald of a fiberoptic bronchoscope. Light and transmiselon electron microscopy studies of tissues from lung lobes instilled with SRBC showed perivascular infiltrates and intre-alveolar accumulations of lymphoid cells which were not present in control lung lobes. The morphology of these lymphold cells ranged from small lymphocytes through mature plasma cells. From 5\% to $15 \%$ of the cells present in the interstitial tissues and alveoll of immunized lung lobes were plasma cells. These observations suggest that lymphoid cells which entered the SRBC immunized lung can mature to plasma cells which are probably responsible for the local production of antigen-specific antibody.
\end{abstract}

Key words: lung immunity, antibody-forming cells

\section{INTRODUCTION}

The deposition of particulate antigen in selected airways of single lung lobes of chimpanzees, cynomolgus monkeys, and dogs with a fiberoptic bronchoscope has been used to study the development of localized lung immune responses [1-3]. The evaluation of cells and proteins obtained in sequential lavages of immunized and control lung lobes indicate that specific antibody-forming cells (AFC) are found predominantly in the immunized lung lobes, although some AFC are also present in lavage fluid from control lung lobes [1-3]. Published data suggest that these AFC are produced in the lung-associated lymph nodes which receive lymphatic drainage from the lung lobes exposed to antigen [4]. AFC leave the lungassociated lymph nodes and enter blood, and in primary immunizations, the blood appears to be the source of AFC which accumulate in the lung lobes exposed to antigen [5, 6]. These AFC enter predominantly into immunized lung lobes after a primary immunization by nonspecific changes in vascular permeability produced by antigen exposure [7].

The results of numerous studies have shown that a localized production of antibody occurs in lung mucosal tissues [8]. As indicated above, large numbers of AFC are present in the alveoli and interstitial tissues of immunized lung lobes. Published data suggest that these cells are secreting antigen-specific IgM, IgG, and IgA antibody $[7,9]$. These data, and the presence of antibodysecreting B lymphocytes in efferent lymph from antigenstimulated lymph nodes and in the blood of immunized animals and man [10-13], all suggest that an important part of the immune system includes the production of B lymphocytes which can home to specific tissues. These tissues include those which were originally exposed to the immunizing antigen. Theoretically, B lymphocytes enter these tissues, mature to plasma cells, and secrete antibody locally to provide immune defense.

The Jerne plaque assay and the reverse hemolytic plaque assay have been used to identify antigen-specific AFC in the lung-associated lymph nodes, blood, and lung

Received June 13, 1986; accepted July 23, 1986.

R.H. Gray's present address is the Department of Environmental and Industrial Health, University of Michigan, Ann Arbor, MI 48109.

Reprint requests: David E. Bice, Inhalation Toxicology Research Institute, P.O. Box 5890, Albuquerque, NM 87185. 
lavage fluid from animals and man $[1-4,6,7,9,14-16]$. The presence of AFC and increased total and specific antibody levels in lung lavage fluid [17] supports the concept of local antibody production. However, recent data suggest that the use of sensitive hemolytic plaque assays to enumerate AFC in lung lavage fluid may identify not only lymphoid cells which are actively secreting antibody, but also cells which simply release preformed antibody [18].

The identification of plasma cells by light microscopy in interstitial lung tissues and alveoli of immunized lung lobes suggests that cells capable of local antibody production are present after immunization, and that AFC in lung lavage represents a sample of these cells [5]. However, a definitive identification of plasma cells can be made only at the electron microscope level. Because of concern that the identification of large numbers of AFC in lung lavage fluid may represent a passive release of antibody rather than localized antibody production, we used transmission electron microscopy to evaluate the morphology of lymphoid cells in the interstitial tissues and alveoli of immunized and control lung lobes of dogs and to determine the numbers of plasma cells present. Data from this study showed increased numbers of plasma cells in the interstitial tissues and alveoli of immunized lung lobes at the peak time of immune response. These cells were not present in control lung lobes of immunized dogs.

\section{MATERIALS AND METHODS}

Two 4-yr-old beagle dogs raised at our institute were used in this study. They were fed $350 \mathrm{~g}$ of dry dog food once a day (Allied Mills, Chicago, IL), and water was available at all times. Each dog was given a physical exam at the beginning of this study and found to be healthy. Prior to immunization, the dogs were anesthetized with $4 \%$ halothane gas (Fluothane, Ayerst Laboratories, New York, NY) in oxygen. An Olympus fiberoptic bronchoscope (Model BF-4, Olympus Corp of America, New Hyde Park, NY) was used to identify specific airways for immunization. Sheep red blood cells (SRBC), autologous dog red blood cells (DRBC), or saline were instilled into specific lung lobes as previously described [1]. One milliliter of SRBC in saline $\left(10^{10}\right.$ cells $/ \mathrm{ml}$ ) was instilled into the right apical, right cardiac, right diaphragmatic, and right intermediate lung lobes. The left cardiac lung lobe received $1 \mathrm{ml}$ autologous DRBC $\left(10^{10} \mathrm{cells} / \mathrm{ml}\right)$, while the left diaphragmatic lung lobe received $1 \mathrm{ml}$ saline. The left apical lung lobe was used as an unexposed control lung lobe.

The dogs were sacrificed by intravenous administration of pentobarbital followed by cardiac exsanguination 12 days after immunization. This is the approximate time of peak immune response after lung immunization [3, 7].
The lungs were removed, and the fiberoptic bronchoscope was used to identify control lung lobes and lung lobes exposed to antigen. A polyethylene catheter was inserted through the biopsy channel of the fiberoptic bronchoscope into each lung lobe which was used for immunization or as a control. The bronchoscope was then removed, leaving the catheter in the identified airway. Each catheter was firmly secured by placing a ligature around the proximal portion of bronchus of the lung lobe. Each lung lobe was excised and perfused through the catheter with modified Karnovsky's fixative [19] at $30 \mathrm{~cm}$ pressure for $24 \mathrm{~h}$ at room temperature.

Each lung lobe was sampled at several sites after fixation. Rectangular portions $(3 \times 4 \times 20 \mathrm{~mm})$ were cut from the lobes distal to the end of the catheter. Each of the rectangular tissue pieces was serially cut into ten slices about $2 \mathrm{~mm}$ in thickness. The third and seventh 2 $\mathrm{mm}$ serial slices from each lobe were embedded in paraffin, and $5-\mu \mathrm{m}$ sections were stained by hematoxylin and eosin and examined by light microscopy. These hematoxylin and eosin sections were used as a basis for selecting portions of the adjacent 2-mm slices for transmission electron microscopy studies. Selected tissue slices from the right cardiac lung lobes which contained cellular infiltrates were cut into ten blocks, postfixed in $2 \% \mathrm{OsO}_{4}$ containing $0.1 \mathrm{M}$ cacodylate buffer ( $\mathrm{pH} 7.2$ ), washed and dehydrated in ethanol, and embedded in Epon. Onemicrometer-thick sections were cut from six blocks and stained with toluidine blue for light microscopy. From these same blocks, pale gold sections were prepared using a diamond knife on a LKB8800A Ultratome III (LKB-Produkter, Stockholm, Sweden), mounted on uncoated 200-mesh copper grids, and poststained with uranyl acetate [20], and lead citrate [21]. The lower righthand corner of each grid square covering one section was photographed in a Hitachi HU-11C electron microscope (Hitachi Ltd., Tokyo, Japan) at 75 or $100 \mathrm{kV}$. Photomicrographs were prepared, and the number of lymphoid cells, macrophages, and neutrophils present in the alveoli were counted and expressed as a percent of total cells.

\section{RESULTS}

The light microscopic evaluation of hematoxylin and eosin stained tissue sections showed that the left apical lobes, which received no antigenic stimulation (Fig. 1a), and the left diaphragmatic lobes which received saline (Fig. 1b), were relatively free of any cellular infiltrate. The left cardiac lobes (Fig. 1c), which were exposed to autologous DRBC, had slightly increased numbers of macrophages in alveoli compared to the left apical and left diaphragmatic lobes. There were mild perivascular infiltrates of lymphocytes and macrophages surrounding some small venules and larger vessels. 

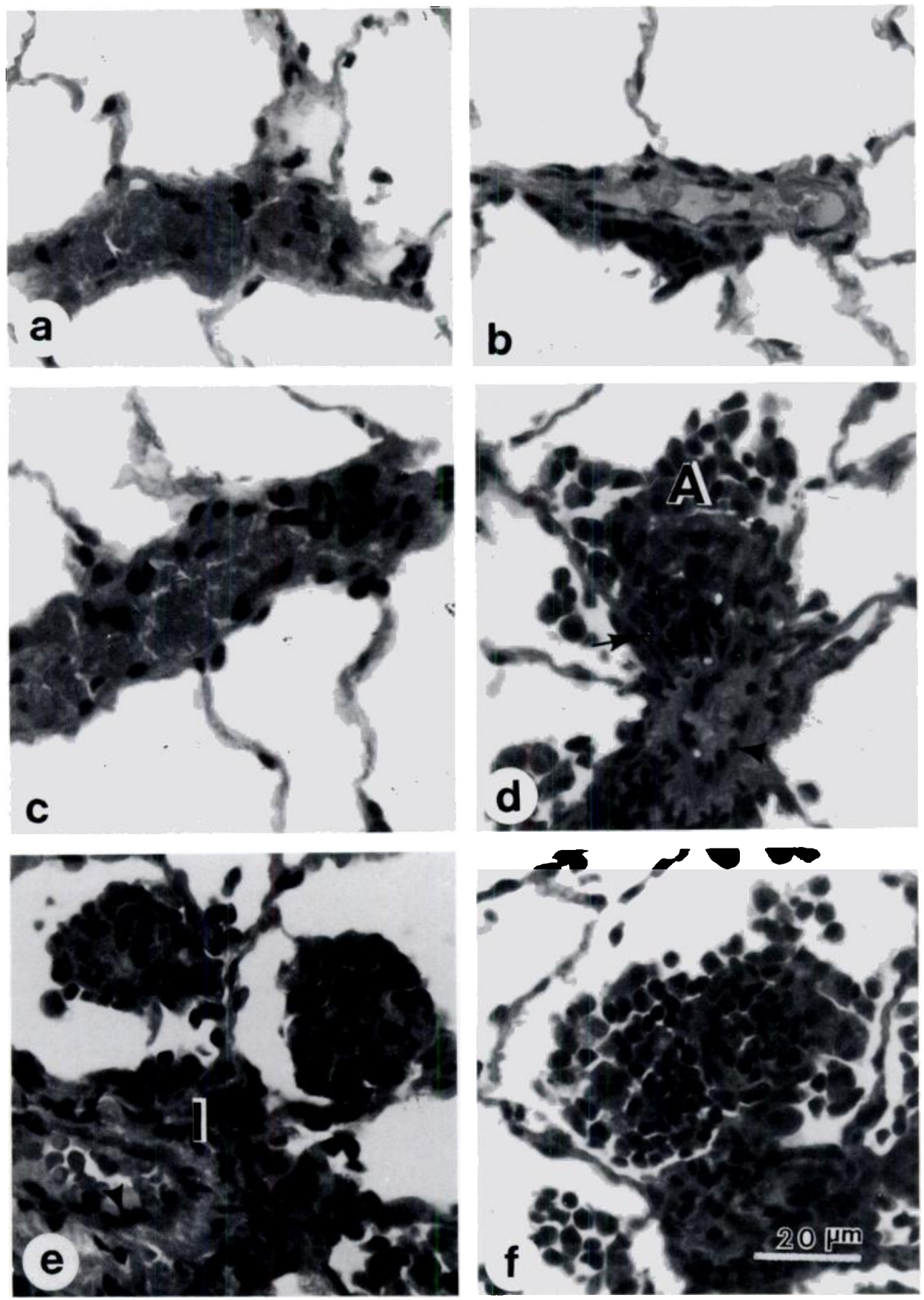

Fig. 1. Comparison of control and immunized beagle lung lobes with hematoxylin and eosin stained sections. $x$ 500. a: No immunization. b: Saline. c: Autologous dog red blood cells (DRBC). d: Immunized with sheep red blood cells (SRBC), showing a perivascular infiltrate (arrow) and lymphoid cells on the lumen of a vascular wall (arrowhead). The cellular infiltrate

The right lobes were immunized with the particulate SRBC antigen (Fig. 1d-f). The evaluation of tissues from each of the immunized lung lobes by light microscopy showed similar responses. Blood vessels in the immu-

extends into the alveolus (A). e: Immunized with SRBC showing lymphoid cells at the periphery of a lumen (arrowhead), a perivascular infiltrate in the interstitium (l) and large intra-alveolar aggregates. f: Immunized with SRBC showing large intra-alveolar aggregates.

nized regions were congested with large numbers of mononuclear cells; lymphoid cells were seen with relatively large areas of their plasma membranes in close apposition with the endothelial surface. Relatively few 
TABLE 1. Percent Cell Types Counted in Transmission Electron Microscope Photomicrographs of Tissues From Immunized Lung Lobes

\begin{tabular}{lcccccc}
\hline & $\begin{array}{c}\text { Alveolar } \\
\text { macrophages }\end{array}$ & Lymphocytes & $\begin{array}{c}\text { Plasma } \\
\text { cells }\end{array}$ & Neutrophils & Other & $\begin{array}{l}\text { Total } \\
\text { cells }\end{array}$ \\
\hline Alveoli & & & & & & \\
Dog 1 & 50.4 & 23.3 & 15.8 & 2.3 & 8.2 & 133 \\
Dog 2 & 69.3 & 18.4 & 5.4 & 0 & 6.9 & 130 \\
$\begin{array}{l}\text { Interstitial tissues } \\
\text { Dog 1 }\end{array}$ & 0 & & & & & \\
Dog 2 & 0 & 22.7 & 6.7 & 0 & 70.6 & 163 \\
\hline
\end{tabular}

aalls that could not be identified by morphologic characteristics.

erythrocytes were seen in these blood vessels. The endothelial lining of the vascular tissue appeared to be intact, and no cells were observed transversing the endothelium. The perivascular infiltrates were predominantly mononuclear cells (Fig. 1e,f).

The alveoli adjacent to the perivascular infiltrates frequently contained compact intra-alveolar infiltrates of cells (Fig. 1d), which in some cross sections nearly filled the entire alveolus (Fig. 1f). Some alveoli contained smaller or more diffuse clusters of cells. Because tissues were taken at 12 days after immunization, few neutrophils were observed. The alveolar septa in the reactive regions of the immunized lung lobes appeared thicker and more irregular than the alveolar septa in the control lung lobes.

The numbers of alveolar macrophages, neutrophils, lymphocytes, and plasma cells present in the immunized lung lobes were identified on transmission electron microscope photomicrographs and counted. The morphology of lymphoid cells in the interstitial tissues and alveoli of immunized lung lobes varied from small lymphocytes through mature plasma cells, which were identified by parallel cisternae of rough endoplasmic reticulum membranes. Approximately 130 alveolar cells were identified in transmission electon microscope photomicrographs from the immunized lung lobes of each of two dogs. Of the alveolar cells identified in each dog, $23.3 \%$ and $18.4 \%$, respectively, were classified as lymphocytes (Table 1). The interstitial tissues contained a similar percentage of lymphocytes (22.7\% and $26.6 \%)$. Because of the difficulty of distinguishing type I cells, fibroblasts, and endothelial cells, the number of cells which were not classified in the interstitial tissues is higher than in the alveoli.

Large numbers of plasma cells, identified in transmission electron microscope photomicrographs, were present in the alveoli (15.8\% and 5.4\%) and interstitial tissues (6.7\% and $7.8 \%$ ) of both dogs (Table 1). Plasma cells were frequently seen in contact with alveolar macrophages (Fig. 2a,b). The varied morphology of the plasma cells suggested that they were in different stages of maturation (Fig. 3). No plasma cells and few lymphoid cells were observed in transmission electron micrographs of tissues from any of the control lung lobes, and counts were not made.

\section{DISCUSSION}

Previous studies have described the histological changes in the lungs of dogs produced by the instillation of particulate antigen [5, 22, 23]. The results showed that instilled SRBC are initially phagocytized by pulmonary alveolar macrophages, and that within a few hours after immunization, increasing numbers of neutrophils enter the immunized lung $[22,23]$. The examination of lung tissue 4 days after immunization showed an increase of lymphoid cells in the perivascular regions [5]. Perivascular infiltrates were seen in immunized lobes starting at 5 days after immunization, with the gradual development of increasing numbers of intra-alveolar mononuclear aggregates. Perivascular infiltrates were also observed in the present study. Large numbers of lymphoid cells were present in the venules, some of which are in direct contact with the endothelium. These observations further support the hypothesis that in primary immune responses, immune lymphocytes are recruited from the blood into the lung [5].

The presence of plasma cells in the alveoli and interstitial tissues of immunized lung lobes suggests that they are the source of locally produced antibody observed after lung immunization in addition to antibody which enters the lung by transudation from the vasculature [5, 17]. The presence of lymphoid cells in perivascular infiltrates and in the intra-alveolar aggregates that vary in maturation from small lymphocytes through mature plasma cells also supports the concept that antigen-specific lymphoid cells enter the immunized lung (possibly as lymphoblasts) [24] and mature to plasma cells.

Studies have shown that lymphoid cells secreting antibody are present in blood [10-13], and in lavage fluid and tissues of the normal human lung [14-16]. Lung lavage fluids from individuals with lung disease contain large numbers of AFC [15, 16]. Because AFC in lavage fluid from the human lung are usually identified with the 

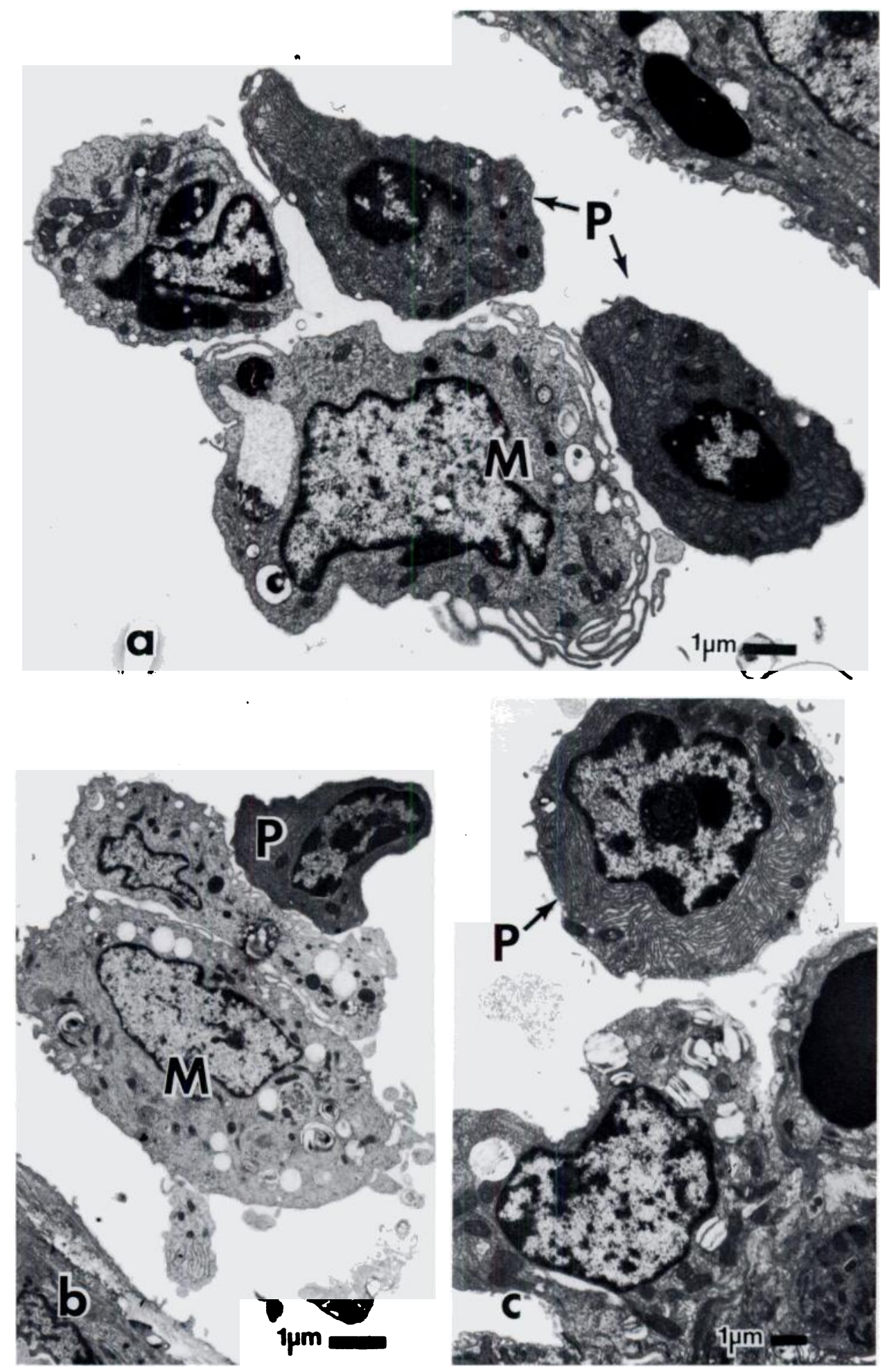

Fig. 2. Immunized lung lobe whth intra-alveolar cells consisting of plasma cells (P) and macrophages (M). a, × 8,000; b, X 7,000; c, × 5,000.

reverse hemolytic plaque assay, it is possible that these AFC are releasing preformed antibody rather than secreting antibody [18]. However, the identification of ma- ture plasma cells in immunized lung lobes in the present study supports the possibility that AFC in the lungs of humans are producing antibody. A comparison of data 

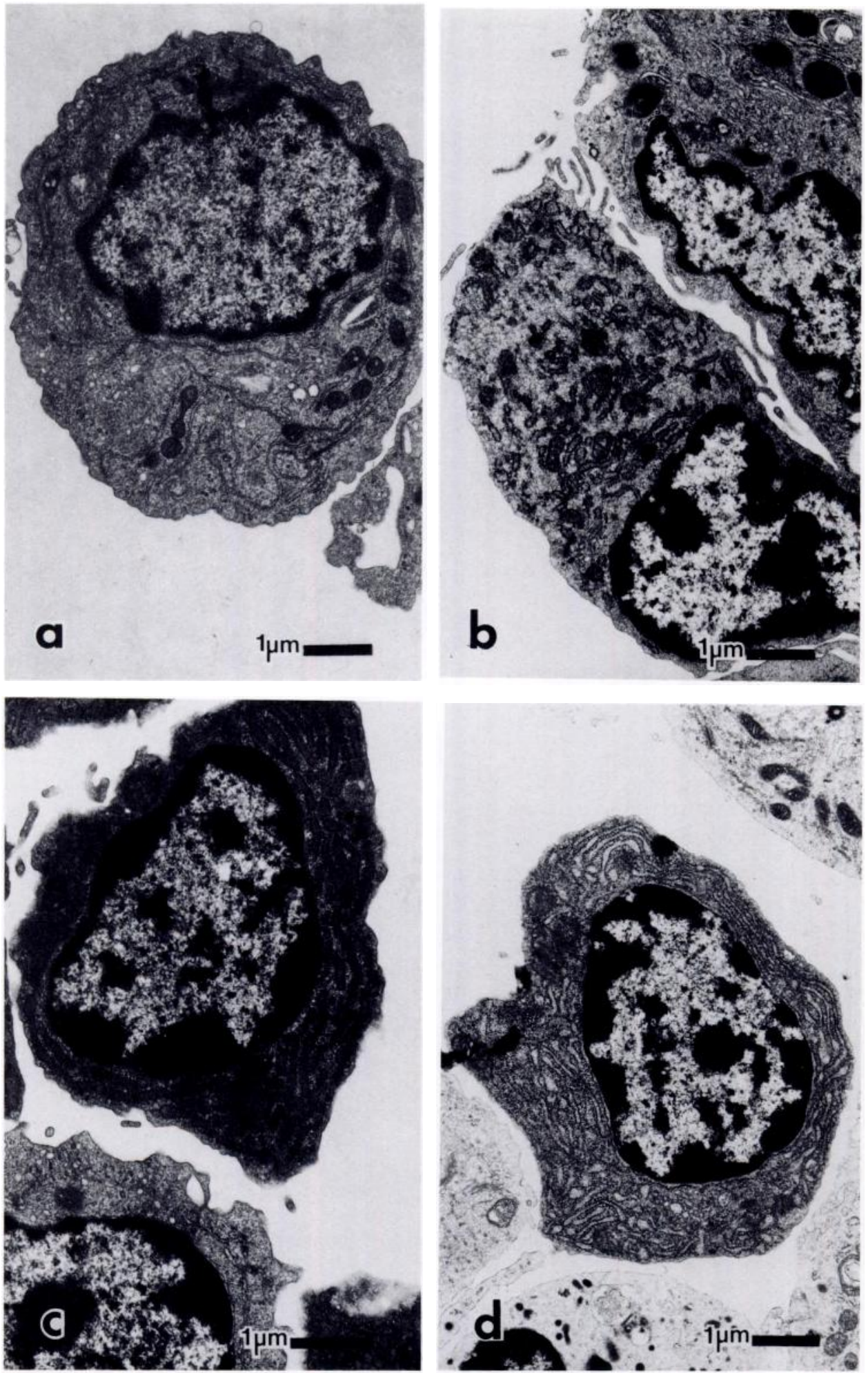

Fig. 3. Plasma cells showing apparent differences in maturation (a-d) in the immunized dog lung alveoll at 12 days after immunization. $a, \times 9,000 ; b, \times 9,000 ; c$, $\times 11,000 ; d, \times 9,000$. 
from chimpanzee, cynomolgus monkeys, and dogs indicate that the dog has basically the same lung immune response as observed in nonhuman primates. The limited data available from humans $[10,11,15,16]$ also suggests that the dog is probably a good model for human lung immunity. If AFC identified in lavage fluid from the human lung are actively secreting antibody, additional data are needed concerning their roles in immunologic responses normally providing defense, as well as the possibility that elevated numbers of AFC in the human lung may lead to lung damage.

\section{ACKNOWLEDGMENTS}

The authors thank the animal care personnel of the Inhalation Toxicology Research Institute for their care and handling of the animals, and Larry A. Martinez for his assistance in the preparation of the photomicrographs used. This research was performed under U.S. Department of Energy Contract Number DE-ACO4-76EV01013 in facilities fully accredited by the American Association for the Accreditation of Laboratory Animal Care.

\section{REFERENCES}

1. Bice, D.E., Harris, D.L., Muggenburg, B.A., and Bowen, J.A. The evaluation of lung immunity in chimpanzees. Am. Rev. Respir. Dis. 126, 358, 1982.

2. Mason, M.J., Bice, D.E., and Muggenburg, B.A. Local pulmonary immune responsiveness after multiple antigenic exposures in the cynomolgus monkey. Am. Rev. Respir. Dis. 132, 657, 1985.

3. Bice, D.E., Harris, D.L., Hill, J.O., Muggenburg, B.A., and Wolff, R.K. Immune responses in the dog after localized lung immunization. Am. Rev. Respir. Dis. 122, 755, 1980.

4. Bice, D.E., Harris, D.L., and Muggenburg, B.A. Regional immunologic responses following localized deposition of antigen in the lung. Exp. Lung Res. 1, 33, 1980.

5. Brownstein, D.G., Rebar, A.H., Bice, D.E., Muggenburg, B.A., and Hill, J.O. Immunology in the respiratory tract. Serial morphologic changes in the lungs and tracheobronchial lymph nodes of dogs after intrapulmonary immunization with sheep erythrocytes. Am. J. Pathol. 98, 499, 1980.

6. Kaltreider, H.B., Barth, E., and Pellegrini, C. The effect of splenectomy on the appearance of specific antibody-forming cells in lungs of dogs after intravenous immunization with sheep erythrocytes. Exp. Lung Res. 2, 231, 1981.

7. Bice, D.E., Degen, M.A., Harris, D.L., and Muggenburg, B.A. Recruitment of antibody-forming cells in the lung after local immunization is nonspecific. Am. Rev. Respir. Dis. 126, 635, 1982.
8. Woloschak, G.E., and Tomasi, T.B. The immunology and molecular biology of the gut-associated immune system. CRC Crit. Rev. Immunol. 4, 1, 1983.

9. Bice, D.E., and Muggenburg, B.A. Effects of age on antibody responses after lung immunization. Am. Rev. Respir. Dis. 132, $661,1985$.

10. Thomson, P.D., and Harris, N.S. Detection of plaque-forming cells in the peripheral blood of actively immunized humans. J. Immunol. 118, 1480, 1977.

11. Stevens, R.H., Macy, E., Morrow, C., and Saxon, A. Characterization of a circulating subpopulation of spontaneous antitetanus toxoid antibody producing B cells following in vivo booster immunization. J. Immunol. 122, 2498, 1979.

12. Yarchoan, R., Murphy, B.R., Strober, W., Clements, M.L., and Nelson, D.L. In vitro production of anti-influenza virus antibody after intranasal inoculation with cold-adapted influenza virus. J. Immunol. 126, 1958, 1981.

13. Brieva, J.A., Targan, S., and Stevens, R.H. NK and T cell subsets regulate antibody production by human in vivo antigeninduced lymphoblastoid B cells. J. Immunol. 132, 611, 1984.

14. Lawrence, E.C., Blaese, R.M., Martin, R.R., and Stevens, P.M. Immunoglobulin secreting cells in normal human bronchial lavage fluids. J. Clin. Invest. 62, 832, 1978.

15. Rankin, J.A., Naegel, G.P., Schrader, C.E., Matthay, R.A., and Reynolds, H.Y. Air-space immunoglobulin production and levels in bronchoalveolar lavage fluid of normal subjects and patients with sarcoidosis. Am. Rev. Respir. Dis. 127, 442, 1983.

16. Rankin, J.A, Walzer, P.D., Dwyer, J.M., Schrader, C.E., Enriquez, R.E., and Merrill, W.W. Immunologic alterations in bronchoalveolar lavage fluid in the acquired immunodeficiency syndrome (AIDS). Am. Rev. Respir. Dis. 128, 189, 1983.

17. Hill, J.O., Bice, D.E., Harris, D.L., and Muggenburg, B.A. Evaluation of the pulmonary immune response by analysis of bronchoalveolar fluids obtained by serial lung lavage. Int. Arch. Allergy Appl. Immunol. 71, 173, 1983.

18. Hance, A.J., Zimmerman, R., Crystal, R.G. Is the human lung a site of immunoblobulin synthesis? Am. Rev. Respir. Dis. 129, A6, 1984.

19. Dungworth, D.L., Schwarte, L.W., Tyler, W.S., and Phalen, R.F. Morphological methods for evaluation of pulmonary toxicity in animals. Ann. Rev. Pharm. Toxicol. 16, 381, 1976.

20. Hayat, M. Principles and Techniques of Electron Microscopy, Vol. 1. New York: Van Nostrand Reinhold, 1970.

21. Reynolds, E.S. The use of lead citrate at high $\mathrm{pH}$ as an electronopaque stain in electron microscopy. J. Cell. Biol. 17, 208, 1963.

22. Kaltreider, H.B., Turner, F.N., and Salmon, S.E. A canine model for comparative study of respiratory and systemic immunologic reactions. Am. Rev. Respir. Dis. 111, 257, 1975.

23. Kaltreider, H.B., Caldwell, J.L., and Adam, E. The fate and consequence of an organic particulate antigen instilled into bronchoalveolar spaces of normal canine lungs. Am. Rev. Respir. Dis. 116, 267, 1977.

24. Spencer, J.O., and Hall, J.G. Studies on the lymphocytes of sheep. IV. Migration patterns of lung-associated lymphocytes efferent from the caudal mediastinal lymph node. Immunology $52,1,1984$. 